VAK 343.7

ББК 67.408 .12

DOI 10.22394/1682-2358-2019-2-66-71

G.V. Vershitskaya, Candidate of Sciences (Law), Docent of the Administrative and Criminal Law Department, Povolzhsky Institute of Management named after P.A. Stolypin, Branch of the Russian Presidential Academy of National Economy and Public Administration

\section{PECULIARITIES \\ OF LEGAL \\ QUALIFICATION \\ OF FRAUD \\ IN THE INSURANCE SPHERE}

Legal issues related to the qualification of fraudulent actions in the field of civil liability insurance of vehicle owners are considered. Modern law enforcement practice in the field of this type of insurance is analyzed. The issues of application of the current legislation for legal qualification of various types of fraud in the insurance sphere are covered. Proposals on possible solution of the identified problems are formulated.

Key words and word-combinations civil liability insurance, insurance fraud, qualification of various types of fraud.
Г.В. Вериичкая, кандидат юридиеских наук, доиент кафедрь административного и уголовного права Поволжского института управления имени П.А. Стольпина - филиала Российской академии народного хозяйства и государственной службь при Президенте РФ (email:vershickaya@yandex.ru)

\section{ОСОБЕННОСТИ ПРАВОВОЙ КВААИФИКАЦИИ МОШЕННИЧЕСТВА В СТРАХОВОЙ СФЕРЕ}

Аннотация. Рассматриваются правовые вопросы, связанные с квалификацией мошеннических действий в сфере страхования гражданской ответственности владельцев транспортных средств. Анализируется современная правоприменительная практика по рассматриваемому виду страхования. Обсуждаются вопросы применения действующего законодательства для правовой квалификации различных видов мошенничества в страховой сфере. Формулируются предложения по возможному решению выявленных проблем.

Ключевые слова и словосочетания: страхование гражданской ответственности, мошенничество в страховой сфере, квалификация различных видов мошенничества.

$\mathrm{H}_{3}$ ночной экономики в Российской ФеАерации проблема правовой регламентации обязательного страхования гражданской ответственности вцадельев транспортных средств является крайне важной. Обязательное страхование транспорта становится самым крупным и Аинамично развивающимся сек- 
тором рынка страхования физических миџ. Его суть заключается в том, что страховщик обязуется возмещать ущерб, причиненный жизни, здоровью или имуществу граждан транспортным средством страхователя.

25 апреля 2002 г. в цемях защиты прав потерпевших бым принят Федеральный закон № 40-Ф3 «Об обязательном страховании гражданской ответственности владельцев транспортных средств», который определил правовые, экономические и организационные основы рассматриваемого вида страхования. Федеральный закон гарантирует потерпевшему возмещение вреда, причиненного его жизни, зАоровью или имуществу транспортным среАством страхователя в установленных законом пределах [1]. Кроме того, указанный Закон требует всеобщего обязательного страхования гражданской ответственности вцадельцами транспортных средств и не допускает использования на территории России транспортных средств, владелыцы которых не застраховали свою гражданскую ответственность. Аанные требования, основанные на экономической заинтересованности владельцев транспортных средств, количество которых с каждым годом неуклонно возрастает, направлены на обеспечение безопасности Аорожного Авижения.

Права и законные интересы физических миџ, явмяющихся потерпевшими или страхователями, в случаях неисполнения или ненадлежащего исполнения страховщиком обязательств по Аоговору обязательного страхования подлежат защите в соответствии с Федеральным законом от 7 февраця 1992 г. № 2300-1 «О защите прав потребителей» в части, не урегулированной Федеральным законом № 40-Ф3. Надлежащим исполнением страховщиком своих обязательств по договору обязательного страхования признается осуществление страховой выплаты или выдача отремонтированного транспортного средства [2] .

В специальной митературе в настоящее время активно обсуждаются вопросы, связанные с мошенничеством в страховании транспортных среАств. Именно мошенничество уверенно возглавцяет рейтинг преступлений в страховой сфере, поскольку преАполагает посягательство не только на отношения собственности, но и страховые отношения, в основе которых находится имущество. Страховое мошенничество может совершаться как при заключении, так и в проџессе выполнения договоров об обязательном или добровольном страховании транспортных средств.

Сложность правовых связей межау субъектами страховых отношений и несовершенство действующего отечественного законодательства в сфере страхования обусловливают разнообразие мошеннических действий и определяют установленную тенденџию роста Аанного вида преступлений. Мошеннические действия в сфере страхования могут совершаться всеми субъектами страховых отношений: и руководителями страховых компаний, и страхователями, и страховыми агентами. Противоправные Аеяния, совершаемые перечисленными мицами, Аифференцируются также в зависимости от вида страхования и объекта страховой защиты. Например, страхователи могут умышиенно увемичить страховую сумму объекта страхования; умолчать об обстоятельствах, имеющих значение Аля определения страхового риска; одновременно застраховать объект в нескольких страховых компаниях; инсценировать страховое 
событие в период действия договора страхования (кражу, дорожно-транспортное происшествие, угон, поАжог и Ар.).

Как показывает практика, количество противоправных деяний, связанных с мошенничеством в сфере страхования транспортных среАств, стабильно увеличивается на фоне роста общего числа зарегистрированных преступлений в финансово-кредитной сфере. Кроме того, нельзя не отметить постоянного совершенствования способов данного вида преступных посягательств, дмя которых характерно опредеменное территориальное распределение в зависимости от уровня развития системы страхования и количества потенџиальных страхователей в конкретном регионе. Особо следует подчеркнуть высокий уровень матентности рассматриваемых противоправных Аеяний (порядка 3000\% - гиперлатентность).

Мошенничество в сфере обязательного страхования транспортных среАств, как правило, совершается при наличии ряда квалифиџируюших признаков. В связи с этим возникает проблема квамификаџии рассматриваемых противоправных деяний. Федеральным законом от 29 ноября 2012 г. № 207-Ф3 «О внесении изменений в Уголовный кодекс Российской Федерации и отдемьные законодательные акты Российской Федерации» в Уголовный кодекс РФ введен ряд статей, предусматривающих ответственность за совершение мошеннических действий, в том числе ст. 159.5 УК РФ [3]. Введение в действие данной статьи было вызвано необходимостью разграничить состав преступмения, предусмотренный ст. 159 УК РФ «Мошенничество», от Аругих виАов мошенничества с меньшей общественной опасностью, за совершение которых предусмотрено более мягкое наказание. В соответствии с чч. 2-4 ст. 159.5 УК РФ квалифицирующими признаками страхового мошенничества явмяется его совершение:

- группой Аиџ по предварительному сговору;

- с причинением значительного ущерба гражданину;

- лицом с использованием своего служебного положения, а равно в крупном размере;

- организованной группой мибо в особо крупном размере [4] .

Содержание каждого из квалифицирующих признаков страхового мошенничества достаточно подробно рассмотрено в специальной китературе. Например, совершение преступмения группой миџ по предварительному сговору [5] ; совершение преступления киџом с использованием своего служебного положения [6] ; совершение преступления организованной группой [7].

Поскольку отношения в страховой сфере являются разновидностью пубмичных отношений, им в полной мере присущи спещифические признаки гражданско-правового характера. ОАним из таких признаков является Аоговорный характер данных правоотношений, состоящий в обязательности определения сторон договора - страховатемя и страховщика. В связи с этим необходимо разграничивать мошенничество в сфере страхования с Аругими видами гражданско-правовых отношений по объективным и субъективным признакам [8]. Прежде всего это касается змоупотребления правом на страховую выплату. Если страховщик заключает договор страхования, условия 
которого заведомо не соответствуют закону, то на основании ст. 10 ГК РФ единственной целью заключения такого договора можно считать причине-

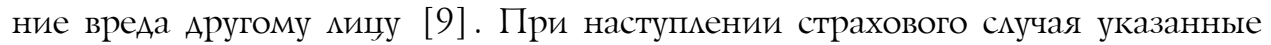
условия делают невозможным осуществление страховой выплаты. В Аанной ситуации умысем страховщика завладеть страховой премией без реацьного исполнения обязательств по договору страхования является очевидным, а его действия квалифицируются по ст. 159 УК РФ как мошенничество.

Правоприменительной практике известны также случаи, когда правом на страховую выплату змоупотребцяет страхователь, совершая одновременное страхование гражданской ответственности в несколыких страховых компаниях. В таких случаях страховщик не отвечает за послеАствия, наступившие из-за недобросовестных действий страхователя, квалифицируемых по ст. 159.5 УК РФ. Исковые требования страхователя о взыскании со страховщика процентов за пользование чужими денежными средствами и компенсации морального вреда удовлетворению не подлежат. Таким образом, с целью разграничения уголовно наказуемого деяния и гражданско-правового деликта, а именно змоупотребления правом на страховую выплату, необходимо в каждом конкретном случае устанавцивать нацичие всех признаков состава преступиения, предусмотренного ст. 159 или 159.5 УК РФ.

Непосредственное отношение к рассматриваемой проблеме имеет постановцение Пценума Верховного Суда РФ «О судебной практике по делам о мошенничестве, присвоении и растрате», которое освещает некоторые вопросы разграничения состава мошенничества и составов иных преступлений, хотя и не учитывает специфику правоотношений, охраняемых ст. 159.5 УК РФ. На наш взгляд, целесообразно рассмотреть некоторые вопросы разграничения мошенничества в сфере страхования со смежными преступлениями.

Аля квалификации противоправного деяния в сфере страхования по ст. 159.5 УК РФ большое значение имеют такие признаки, как объект и предмет мошенничества. Объектом мошенничества в сфере страхования следует считать правомочия страховщиков по владению, пользованию и распоряжению имуществом, принадлежкащим им по праву собственности, а предметом мошенничества в Аанной сфере является имущество страховщика, выплачиваемое в качестве страхового возмещения. Например, Аействия миџа, получающего страховую выплату за Аругое миџо по подложным документам, нельзя считать мошенничеством в сфере страхования, поскольку материальный ущерб несет не страховая компания, а физическое мицо. В Аанном случае противоправное деяние необходимо квалифицировать по ст. 159 УК РФ.

Если же виновный предварительно похитил страховые документы, то в соответствии с п. 11 постановления Пленума Верховного Суда РФ № 51 его действия Аополнительно квалифицируются по ч. 1 ст. 325 УК РФ (если похищен офиџиальный документ) мибо по ч. 2 этой же статьи (если похищен паспорт или иной мичный Аокумент) [10] .

Мошеннические Аействия, в том числе и в сфере страхования, как правимо, осуществляются с использованием подложных документов. В рассматриваемых случаях это документы на незаконное получение страховой выплаты. 
Противоправные деяния, совершенные с использованием подложных документов, квалифиџируются по совокупности ст. 159 и ст. 327 УК РФ. ПодАелка документов сама по себе не явмяется видом мошенничества, поскольку дмя совершения хишения путем мошенничества необходим обман и змоупотребмение Аоверием.

Особый интерес представмяют действия страхователя и страховщика, совершенные в соучастии. В случаях, когда указанные миџа явмяются организаторами, подстрекателями мибо пособниками, их действия следует квалифицировать по чч. 3-5 ст. 33 УК РФ и по соответствующим пунктам ст. 160 УК РФ.

Таким образом, на основании изможкенного можно сделать следующие выВОАЫ.

Во-первых, с целью разграничения мошенничества в страховой сфере и злоупотребления правом на страховую выплату в каждом конкретном случае необходимо устанавливать наличие всех признаков состава преступления, преАусмотренного ст. 159 или 159.5 УК РФ.

Во-вторых, преступиение может быть квалифиџировано по ст. 159.5 УК РФ только при наличии следующих обязательных признаков:

- в качестве объекта мошенничества должны выступать правомочия страховщика по владению, пользованию и распоряжению имуществом на правах собственности;

- субъектом мошенничества в сфере страхования должен быть страхователь, в отличие от порядка, установленного в ст. 159 УК РФ;

- наступление страхового случая и определение размера страхового возмещения страхователю или иному мищу в соответствии с Аоговором Аолжно быть связано с обманом или змоупотреблением доверием.

B-третьих, противоправное деяние, совершенное с использованием подможного документа, предоставляющего право на страховую выплату, квалифицируется как совокупность преступлений, предусмотренных ч. 3 ст. 327 УК РФ и ч. 1 ст. 159.5 УК РФ.

В-четвертых, при разграничении ч. 3 ст. 159.5 УК РФ и ст. 160 УК РФ с џелью квалификаџии действий миџа как мошеннических необходимо установить факт фальсификаџии страхового случая. При отсутствии фальсификации содеянное квалифиџируется как присвоение или растрата.

В-пятых, если мошенничество в сфере страхования совершило должностное киџо, что выразилось в хищении страховой выплаты, содеянное квалифицируется по ч. 3 ст. 159.5 УК РФ, а дополнительная квалификация по ст. 285 УК РФ не требуется.

В-шестых, с целью совершенствования действующего законодательства считаем необходимым внести следующие изменения в п. 7 постановяения Пиенума Верховного Суда РФ от 27 декабря 2007 г. № 51 «О судебной практике по декам о мошенничестве, присвоении и растрате»: «Аеяния, предусмотренные ч. 1 ст. 159.5 УК РФ, совершенные с использованием изготовленного Аругим мицом подцельного официального документа, подлежкат квалификации по совокупности части 1 статьи 159.5 УК РФ и части 3 статьи 327 УК РФ. В иных 
случаях хищение миџом чужого имущества или приобретение права на него путем обмана или змоупотребления доверием, совершенные с использованием изготовценного Аругим Аиџом подАельного офиџиального Аокумента, по ностью охватывается составом мошенничества и не требует Аополнительной квалификации по статье 327 УК РФ».

В-седьмых, предупреждение мошеннических действий в сфере обязательного страхования транспортных средств возможно обеспечить принятием слеАующих мер, направленных на совершенствование деятельности страховых компаний:

- создание общероссийской базы данных по учету заключенных договоров обязательного страхования гражданской ответственности вмадельцев транспортных средств;

- информирование населения о банкротстве страховых компаний, о мишении их миџензий на осуществление страховой деятельности, а также о случаях страхового мошенничества и способах его совершения;

- введение государственной аттестации страховых агентов.

Своевременное выявление и пресечение преступлений в страховой сфере в значительной степени зависит от грамотной работы субъектов страхования на всех этапах заключения и исполнения договоров при обязательном взаимодействии со страховой экспертизой, контрольно-ревизионными служкбами, подразделениями по защите информаџии и безопасности страховой деятельности.

\section{Библиографический список}

1. Об обязательном страховании гражданской ответственности владельцев транспортных средств: Федер. закон от 25 апр. 2002 г. № 40-Ф3 [Электронный ресурс]. Доступ из СПС «КонсультантПлюс».

2. О защите прав потребителей: Закон РФ от 7 февр. 1992 г. №2300-01 (в ред. от 1 мая 2017 г.). URL: https://fzakon.ru/laws/zakon-rf-ot-07.02.1992-n-2300-1/

3. О внесении изменений в Уголовный кодекс Российской Федерации и отдельные законодательные акты Российской Федерации: Федер. закон от 29 нояб. 2012 г. № 207-ФЗ (с изм. и доп.) [Электронный ресурс]. Доступ из СПС «КонсультантПлюс».

4. Уголовный кодекс Российской Федерации от 13 июня 1996 г. № 63-ФЗ (в ред. от 27 дек. 2018 г. с изм. и доп.; вступил в силу с 8 янв. 2019 г.). URL: http://legalacts.ru/kodeks/UK-RF/

5. Жилкина М.С. Страховое мошенничество: Правовая оценка, практика выявления и методы пресечения. М., 2005.

6. Вершицкая Г.В. Особенности правовой квалификации коррупционных правонарушений // Вестник Поволжского института управления. 2017. Т. 17, № 1. С. 18-24.

7. Тюнин В.И. Преступления в сфере экономической деятельности: учебно-практическое пособие. М, 2019.

8. Яблоков Н.П. Криминалистическая методика расследования: История, современное состояние и проблемы. М., 2016.

9. Гражданский кодекс Российской Федерации. Ч. 1 (по сост. на 19 нояб. 2018 г.). URL: https://www.grazkodeks.ru/

10. О судебной практике по делам о мошенничестве, присвоении и растрате: постановление Пленума Верховного Суда РФ от 27 дек. 2007 г. № 51 // Российская газета. Федер. выпуск. 2008. 12 янв. 